\title{
Rumen protein degradation rates estimated by non-linear regression analysis of Michaelis-Menten in vitro data*
}

\author{
BY GLEN A. BRODERICK† \\ US Department of Agriculture, Agricultural Research Service, US Dairy Forage Research Center, \\ 1925 Linden Drive West, Madison, Wisconsin 53706, USA \\ AND MURRAY K. CLAYTON \\ Departments of Statistics and Plant Pathology, University of Wisconsin, \\ Madison, Wisconsin 53706, USA
}

(Received 22 October 1990-Accepted 7 May 1991)

\begin{abstract}
An in vitro method applying Michaelis-Menten saturation kinetics was developed as an alternative approach for estimating protein degradation rates in the rumen. Non-linear regression (NLR) analysis of the integrated Michaelis-Menten equation yielded fractional degradation rates, $k_{\mathrm{d}}$, from direct estimates of the maximum velocity: Michaelis constant ratio $\left(k_{\mathrm{d}}=V_{\max }: K_{\mathrm{m}}\right)$. Degradation rates obtained using data from a series of $2 \mathrm{~h}$ inhibitor in vitro incubations were respectively $0.989,0.134$, and 0.037 / $\mathrm{h}$ for casein, solvent soya-bean meal (SSBM) and expeller soya-bean meal (ESBM). Degradation rates obtained from $2 \mathrm{~h}$ incubations had lower standard errors than those obtained using $1 \mathrm{~h}$ incubations; $2 \mathrm{~h}$ rates were not significantly different from $1 \mathrm{~h}$ rates, suggesting end-product inhibition was not significant at $2 \mathrm{~h}$. The NLR Michaelis-Menten method was used to determine degradation rates for twelve protein sources: casein, bovine serum albumin, two samples of lucerne (Medicago sativa) hay, and four samples each of SSBM and ESBM. Statistical analysis of NLR results revealed significant differences among the twelve protein sources. Casein was degraded most rapidly $(0.827 / \mathrm{h})$, and the four ESBM samples most slowly (0.050-0.098 /h). Degradation rate for serum albumin was $0.135 / \mathrm{h}$; rates for SSBM and lucerne hays ranged from 0.160 to 0.208/h. Degradation rates estimated using the NLR method were more rapid than those obtained with a limited substrate approach; NLR rates were more consistent with in vivo estimates of rumen protein escape. Greater concentrations of slowly degraded proteins were needed with the NLR method to define curvilinearity of the degradation curve more accurately.
\end{abstract}

Protein degradation rate: Rumen protein escape: Michaelis-Menten kinetics: Non-linear regression

Rumen degradation of feed proteins may exceed microbial protein synthesis; degradation often results in wastage of dietary protein, particularly in productive ruminants such as dairy cows which have high protein requirements. Indeed, studies have indicated that feeding proteins which are resistant to microbial breakdown in the rumen, such as fishmeal (Oldham et al. 1985; Ørskov et al. 1987) or roasted soya-beans (Faldet \& Satter, 1991), significantly increased production of milk and milk protein. Therefore, determination of the rate and extent of rumen degradation is critical when evaluating dietary proteins.

Overall rate of protein degradation has been estimated by in situ techniques and in vitro methods using rumen inoculum or commercial enzymes (Nocek, 1988). Fractional rates of microbial protein degradation were determined using short-term incubations with limited amounts of substrate (i.e. with enzyme activity in excess) in an inhibitor in vitro (IIV)

\footnotetext{
* Mention of commercial products in the paper does not constitute endorsement by the US Department of Agriculture or the Agricultural Research Service.

$\dagger$ For reprints. 
system and extents of protein escape were computed based on typical rates of rumen passage (Broderick, 1987). These IIV results correlated well with in situ data (Broderick et al. 1988), successfully quantified relative differences in lactation performance of cows fed solvent (SSBM) and expeller soya-bean meal (ESBM; Broderick, 1986; Broderick et al. 1990 ), and identified the extent of roasting required for optimal protection of protein in soya beans (Faldet et al. 1988). However, a limited substrate approach with the IIV procedure may have several significant limitations: (1) degradation rates are computed from the appearance of ammonia and free amino acids in the presence of inhibitors of their metabolism and, thus, the system may be susceptible to end-product inhibition; (2) degradation rates determined for feeds with high $\mathrm{NH}_{3}$ and amino acids (e.g. forages and especially lucerne (Medicago sativa) silages) are less accurate because breakdown of more slowly degraded residual protein must be computed from appearance of additional $\mathrm{NH}_{3}$ and free amino acids in the presence of high backgrounds; (3) quantifying degradation rates from the gentle slopes obtained with slowly degraded proteins is less accurate; (4) the limited substrate restriction amplifies weighing errors. Moreover, the original method involved regressions of transformed data, as logs of proportion undegraded, on time (Broderick, 1987), rather than direct fitting of untransformed data (Motulsky \& Ransnas, 1987).

A Michaelis-Menten approach using the IIV system was suggested (Broderick, 1978) in which fractional degradation rate, $k_{\mathrm{d}}$, would be estimated as the tangent through the origin of the velocity vs. substrate concentration ([S]) curve, and determined from the ratio maximum velocity: Michaelis constant (i.e. $k_{\mathrm{d}}=V_{\max }$ : $K_{\mathrm{m}}$; Mahler \& Cordes, 1966). This approach overcomes several limitations of the limited substrate procedure and may yield more accurate estimates of degradation rates. The objective of the present research was to develop and test a Michaelis-Menten method, based on the IIV procedure, for estimating fractional rates of rumen protein degradation from the relationship: $k_{\mathrm{d}}=V_{\max }: K_{\mathrm{m}}$.

\section{MATERIALS AND METHODS}

\section{Materials}

The proteins used in these studies were obtained from the following sources: casein and bovine serum albumin (BSA) were from Sigma Chemical Co. (St Louis, MO, USA); five samples each of SSBM and ESBM, and two samples of lucerne hay were from previous feeding studies conducted with lactating dairy cows (Broderick, 1986; Shaver et al. 1986; Broderick et al. 1990). Buffer-insoluble residues were prepared from two soya-bean meals (SSBM (1/84) and ESBM (1/84)) using McDougall's buffer (Craig \& Broderick, 1981), scaled to $100 \mathrm{~g}$ dry matter (DM), with two buffer washes following the initial extraction. Following extraction and each wash, residues were concentrated by centrifugation $\left(15300 \mathrm{~g}, 15 \mathrm{~min}, 4^{\circ}\right)$; final residues were lyophilized. The sources and purity of chemicals and reagents used in the in vitro incubations and sample analysis were described earlier (Broderick, 1987).

\section{Incubation procedure}

'Michaelis-Menten' incubations were conducted with different protein sources in four separate experiments: (1) casein, SSBM (10/85) and ESBM (10/85); (2) casein, BSA, SSBM $(1 / 84)$ and ESBM $(1 / 84)$ incubated for either $1 \mathrm{~h}$ or $2 \mathrm{~h}$; (3) twelve protein sources, including casein and BSA, two samples of lucerne hay, plus four samples each of SSBM and ESBM; (4) seven protein sources, casein, BSA, a mixture with $500 \mathrm{mg} \mathrm{N} / \mathrm{g}$ total $\mathrm{N}$ each from casein and BSA, SSBM (1/84), buffer-insoluble residue from SSBM (1/84), ESBM $(1 / 84)$ and buffer-insoluble residue from ESBM (1/84). Expts 2 and 3 were conducted in 
1985, Expt 1 in 1986, and Expt 4 in 1990. Rates of degradation and estimated extents of rumen escape, obtained using 'limited substrate' IIV incubations which were reported previously for the proteins studied in Expt 1 (Broderick, 1986) and Expt 3 (Broderick, 1987), were determined at the same time as the 'Michaelis-Menten' measurements.

'Michaelis-Menten' studies were conducted using the IIV procedure of Broderick (1987). Rumen donor animals were rumen cannulated, lactating dairy cows receiving (g/kg DM) : 300 lucerne hay or lucerne silage, 300 maize silage, 300 ground shelled maize, 90 soya-bean meal, 5 salt, 5 dicalcium phosphate, and supplemented with vitamins and trace minerals. In vitro inoculum was enriched with particle-associated microbes as described by Craig et al. (1984), except that rumen contents were not chilled before squeezing through cheese cloth. The final medium contained $1.0 \mathrm{~mm}$-hydrazine and $30 \mu \mathrm{g}$ chloramphenicol $/ \mathrm{ml}$ (inhibitors of microbial uptake of $\mathrm{NH}_{3}$ and amino acids), and $300 \mathrm{ml}$ strained rumen fluid (SRF)/1. 'Michaelis-Menten' incubations were conducted at $39^{\circ}$ in $50 \mathrm{ml}$ centrifuge tubes with duplicates at each level of added protein. Six to eight protein concentrations were used in each experiment; protein was weighed into tubes in amounts equivalent to: $1 \cdot 5,3 \cdot 0,4 \cdot 5,6 \cdot 0,9 \cdot 0,12$ and $18 \mathrm{mg}$ nitrogen/tube (Expt 1); 1.5, 3.0, $4 \cdot 5,6 \cdot 0,12$ and $18 \mathrm{mg} \mathrm{N} /$ tube (Expts 2 and 3); and 1.5, 3.0, 4.5, 6.0, 9.0, 12 and $15 \mathrm{mg} \mathrm{N} /$ tube (casein, BSA and casein plus BSA), and 1.5, 3.0, 4.5, 6.0,9.0, 12, 18 and $36 \mathrm{mg} \mathrm{N} /$ tube (SSBM, ESBM and buffer-extracted SSBM and ESBM; Expt 4). Protein sources were weighed into tubes and wetted with $5 \mathrm{ml}, 39^{\circ} \mathrm{McDougall}$ 's buffer $1 \mathrm{~h}$ before incubation. Twelve to sixteen blank tubes were used in each incubation. Incubations were begun by addition of $10 \mathrm{ml}$ inoculum/tube (total $15 \mathrm{ml}$ medium/tube); tubes were gassed with oxygen-free carbon dioxide and capped with stoppers equipped with Bunsen valves. Incubations were stopped by addition of $1.25 \mathrm{ml}$ trichloroacetic acid (TCA; $650 \mathrm{~g} / 1$ ) to each tube (final TCA concentration $50 \mathrm{mg} / \mathrm{ml}$ ); tubes were held for $30 \mathrm{~min}$ on ice and $4 \mathrm{ml}$ portions centrifuged $\left(15300 \mathrm{~g}, 15 \mathrm{~min}, 4^{\circ}\right)$. Except for Expt 2, all Michaelis-Menten incubations were conducted for $2 \mathrm{~h}$. Incubations were replicated on four separate days in each experiment.

\section{Mathematical analysis}

Velocity of protein degradation, $v$, was normalized per unit inoculum and computed for each protein source at each protein level from net release of $\mathrm{NH}_{3}$ and total amino acids (TAA) using the equation:

$$
v(\mathrm{mg} \mathrm{N} / \mathrm{h} \text { per ml SRF })=\frac{\mathrm{mg} \mathrm{NH}_{3}-\mathrm{N}+\frac{\mu \mathrm{mol} \mathrm{TAA}}{\operatorname{HAA}(\mu \mathrm{mol} / \mathrm{mg} \mathrm{N})}}{\text { time }(\mathrm{h}) \times 4.5 \mathrm{ml} \mathrm{SRF}},
$$

where HAA is the TAA content $(\mu \mathrm{mol} / \mathrm{mg} \mathrm{N})$ determined after acid-hydrolysis of each protein, time is the period of incubation $(1 \mathrm{~h}$ or usually $2 \mathrm{~h}$ ), and $4.5 \mathrm{ml}$ is the equivalent volume of SRF in $15 \mathrm{ml}$ medium. $\mathrm{NH}_{3}$ and free TAA content of proteins before incubation were determined in Expts 1-3 by $0 \mathrm{~h}$ extractions where $100 \mathrm{mg}$ DM (with 3-15 $\mathrm{mg} \mathrm{N}$ ) was added to duplicate tubes containing $15 \mathrm{ml}$ medium, but already treated with $1.25 \mathrm{ml}$ TCA $(650 \mathrm{~g} / 1)$. Zero-hour extracts from casein, BSA and all ten soya-bean meals contained less than $10 \mathrm{~g} \mathrm{~N} / \mathrm{kg}$ total $\mathrm{N}$ as $\mathrm{NH}_{3}$ plus TAA and no corrections were made. Zero-hour extracts from lucerne hay from (10/83) and (10/84) contained respectively 89.6 and $80.6 \mathrm{~g} \mathrm{~N} / \mathrm{kg}$ total $\mathrm{N}$ as $\mathrm{NH}_{3}$ and TAA, and degradation velocities, $v$, were corrected by subtracting these proportions of total $\mathrm{N}$ from degraded $\mathrm{N}$.

Data from Expt 1 were analysed initially by linear regression on Lineweaver-Burk $(1 / v$ vs. 1/[S]) and Eadie-Hofstee ( $v$ vs. $v /[\mathrm{S}]$ ) transformations (Mahler \& Cordes, 1966) to estimate $V_{\max }$ and $K_{\mathrm{m}}$ with units of amount degraded per time per volume of inoculum and 
amount per volume respectively. Fractional degradation rates were computed from: $k_{\mathrm{d}}=V_{\max }: K_{\mathrm{m}}$. Since neither the Lineweaver-Burk nor Eadie-Hofstee plots gives direct estimates of $k_{\mathrm{d}}$, as $V_{\max }: K_{\mathrm{m}}$, several non-linear regression (NLR) techniques were evaluated more properly to estimate $V_{\max }: K_{\mathrm{m}}$ (Cornish-Bowden, 1976; Bates \& Watts, 1988). The Marquardt NLIN procedure of the Statistical Analysis System (SAS; 1985) was used to fit three models: (1) v vs. [S], where $[\mathrm{S}]=\mathrm{S}_{0}$, the amount of protein added at $0 \mathrm{~h}$; (2) $v v s$. [mean $\mathrm{S}]$ (Lee \& Wilson, 1971) where $[$ mean $S]=\left(S_{0}+S_{t}\right) / 2$ and $S_{t}$ is the amount of protein remaining undegraded after incubation (equivalent to PUD (Broderick, 1987)); and (3) the integrated Michaelis-Menten model (IMM), derived from Segal (1976), and consisting of the equation:

$$
\mathrm{S}_{\mathrm{t}}=\mathrm{S}_{0}-t \times k_{\mathrm{d}} \times K_{\mathrm{m}}+K_{\mathrm{m}} \times \ln \left(\mathrm{S}_{0} / \mathrm{S}_{\mathrm{t}}\right)
$$

where $k_{\mathrm{d}}=V_{\max }: K_{\mathrm{m}}$, and other variables are as defined previously. This formulation permits the direct estimation of $k_{\mathrm{d}}$.

That $2 \mathrm{~h}$ incubations may be too long to measure initial rates accurately was addressed in Expt 2. Expt 3 compared degradation rates estimated for twelve proteins using limited substrate with those derived using the IMM. Expt 4 assessed problems related to mixtures of proteins which differ greatly in degradation rate and lack of convergence for slowly degraded proteins such as ESBM.

\section{Chemical analyses}

Determination of inoculum DM content and analysis of TCA supernatant fractions for $\mathrm{NH}_{3}$ and TAA were as described (Broderick, 1987) except that analysis rate was $60 / \mathrm{h}$. All protein samples, including the buffer-insoluble residues, were analysed for DM at $105^{\circ}$ and total Kjeldahl N (Association of Official Analytical Chemists, 1980), and for HAA $(\mu \mathrm{mol} \mathrm{TAA} / \mathrm{mg} \mathrm{N})$ following hydrolysis in $6 \mathrm{M}$-hydrochloric acid at $105^{\circ}$ for $20 \mathrm{~h}$ (Broderick, 1987) with the same analysis system used for TCA supernatant fractions.

\section{Statistical analysis}

Statistical analyses of experimental results were made using the general linear model procedure of SAS (1985). For each protein and for each of the four incubations within each experiment, estimated values of $k_{\mathrm{d}}$ were used as 'data' in a randomized complete block model with blocks comprised of replicates and treatments comprised of protein sources. A protected least significant difference was used to compare the mean estimates of $k_{\mathrm{a}}$ for the various proteins.

\section{RESULTS}

Expt 1

Linear regressions of data from individual incubations were fitted to Lineweaver-Burk, double reciprocal transformations to compute $V_{\max }$ and $K_{\mathrm{m}}$, and initial estimates of fractional degradation rates were obtained from the ratio $k_{\mathrm{d}}=V_{\max }: K_{\mathrm{m}}$. Lineweaver-Burk plots of $1 / v$ vs. $1 /$ [mean $\mathrm{S}]$, where [mean $\mathrm{S}]=\left(\mathrm{S}_{0}+\mathrm{S}_{\mathrm{t}}\right) / 2, \mathrm{~S}_{0}$ is the amount of protein added at $0 \mathrm{~h}$, and $\mathrm{S}_{\mathrm{t}}$ is the amount of protein remaining undegraded after incubation, approximate use of the integrated form of the Michaelis-Menten equation (Lee \& Wilson, 1971). These regressions gave mean (with $\mathrm{SE}$ ) values for $k_{\mathrm{a}}$ of $0.833(0.099), 0.119(0.006)$ and 0.043 $(0.002) / h$, for casein, SSBM (10/85) and ESBM (10/85) respectively. The Marquardt NLR procedure of SAS (1985) was first used to estimate $V_{\max }$ and $K_{\mathrm{m}}$, then $k_{\mathrm{d}}$ also was estimated indirectly from the ratio $k_{\mathrm{d}}=V_{\max }: K_{\mathrm{m}}$. Rate data from individual incubations were fitted to one of two models: (1) v vs. [S], where [S] $=\mathrm{S}_{0}$; or (2) vvs. [mean S] (Lee \& Wilson, 1971), where [mean $\mathrm{S}$ ] is as defined previously. Models 1 and 2 respectively yielded mean (with SE) values of $k_{\mathrm{d}}$ of $0.614(0.092)$ and $0.900(0.158) / \mathrm{h}$ for casein, $0.101(0.012)$ and 0.111 
Table 1. Expt 1. Comparison of rumen protein degradation variables determined using the limited substrate (IIV) or integrated Michaelis-Menten models*

(Values are means with their standard errors from four incubations)

\begin{tabular}{|c|c|c|c|c|c|}
\hline \multirow[b]{2}{*}{ Protein source } & \multirow[b]{2}{*}{ Variable } & \multicolumn{2}{|c|}{ Limited substrate model } & \multicolumn{2}{|c|}{$\begin{array}{l}\text { Integrated } \\
\text { Michaelis-Menten model }\end{array}$} \\
\hline & & Mean & $\mathrm{SE}$ & Mean. & SE \\
\hline \multirow[t]{5}{*}{ Caseint } & $k_{\mathrm{d}}(/ \mathrm{h})$ & 0.395 & $0 \cdot 040$ & 0.989 & $0 \cdot 165$ \\
\hline & $V_{\max }(\mathrm{mg} \mathrm{N} / \mathrm{h}$ per $\mathrm{ml})$ & - & - & $0 \cdot 243$ & 0.032 \\
\hline & $K_{\mathrm{m}}(\mathrm{mg} \mathrm{N} / \mathrm{ml})$ & - & - & 0.268 & 0.052 \\
\hline & $B$ (intercept antilog) $\neq(\%)$ & $101 \cdot 9$ & - & 100 & - \\
\hline & Estimated escape $(\%)$ & 13 & - & 6 & - \\
\hline \multirow[t]{5}{*}{$\operatorname{SSBM}(10 / 85) \dagger$} & $k_{\mathrm{d}}(/ \mathrm{h})$ & $0 \cdot 140$ & 0.022 & $0 \cdot 134$ & $0 \cdot 010$ \\
\hline & $V_{\max }(\mathrm{mg} \mathrm{N} / \mathrm{h}$ per $\mathrm{ml})$ & - & - & 0.176 & 0.029 \\
\hline & $K_{\mathrm{m}}(\mathrm{mg} \mathrm{N} / \mathrm{ml})$ & - & - & $1 \cdot 336$ & $0 \cdot 241$ \\
\hline & $B$ (intercept antilog) $(\%)$ & $99 \cdot 7$ & - & 100 & - \\
\hline & Estimated escape $(\%)$ & 30 & - & 31 & - \\
\hline \multirow[t]{5}{*}{$\operatorname{ESBM}(10 / 85) \dagger$} & $k_{\mathrm{d}}(/ \mathrm{h})$ & 0.024 & $0 \cdot 013$ & 0.048 & 0.010 \\
\hline & $V_{\max }(\mathrm{mg} \mathrm{N} / \mathrm{h}$ per $\mathrm{ml})$ & - & - & 0.097 & 0.005 \\
\hline & $K_{\mathrm{m}}(\mathrm{mg} \mathrm{N} / \mathrm{ml})$ & - & - & $2 \cdot 101$ & 0.547 \\
\hline & $B$ (intercept antilog) $(\%)$ & 93.4 & - & 100 & - \\
\hline & Estimated escape (\%) & 67 & - & $\begin{array}{l}55 \\
(n 2) \|\end{array}$ & - \\
\hline
\end{tabular}

SSBM, solvent-extracted soya-bean meal ; ESBM, expeller-extracted soya-bean meal; $k_{\mathrm{d}}$, fractional degradation rate; $V_{\max }$, maximum velocity; $k_{\mathrm{m}}$, Michaelis-Menten rate constant.

* For details of procedures, see pp. 28-30.

$\dagger$ Degradation data from limited substrate model reported earlier for casein (Broderick, 1987), and SSBM and ESBM (trials 1 and 2, Broderick et al. 1990).

+ Intercept antilog, B, was determined experimentally in 'limited substrate' studies, but was assumed to be $100 \%$ in 'Michaelis-Menten' studies because $0 \mathrm{~h}$ ammonia plus total amino acids accounted for $<1 \%$ of total N.

$\$$ Estimated escape $(\%)=\left[k_{\mathrm{p}} /\left(k_{\mathrm{p}}+k_{\mathrm{d}}\right)\right] \times B$, where $k_{\mathrm{p}}$ is assumed to be $0.06 / \mathrm{h}$ (Broderick, 1987)

$\|$ Results from only two of four incubations were used because of non-convergence.

$(0.015) / h$ for SSBM (10/85), and $0.032(0.003)$ and $0.034(0.003) / h$ for ESBM (10/85). The lower rates obtained using model 1 indicate that significant quantities of substrate were consumed after $2 \mathrm{~h}$ of incubation, particularly for the rapidly degraded proteins casein and SSBM, thus use of [mean S] in model 2 was more appropriate (Lee \& Wilson, 1971).

Direct NLR fitting of data is theoretically sounder than fitting transformed data (Cornish-Bowden, 1976; Motulsky \& Ransnas, 1987; Bates \& Watts, 1988). Therefore, a third approach, IMM, which gives direct estimates of $k_{\mathrm{d}}$, as well as $V_{\max }$ and $K_{\mathrm{m}}$, was developed. The integrated form of the Michaelis-Menten equation was selected because incubations had been conducted for $2 \mathrm{~h}$, thus rates were not likely to be true 'initial rates' (Segal, 1976). Results found using the IMM are compared in Table 1 with results obtained previously (Broderick et al. 1990) in limited substrate incubations. $k_{\mathrm{d}}$ values obtained for SSBM (10/85) were of similar magnitude, as was the proportion estimated to escape the rumen at passage rate, $k_{\mathrm{p}}=0.06 / \mathrm{h}$. However, $k_{\mathrm{d}}$ values obtained for ESBM (10/85) were twice, and those for casein more than twice, the values estimated using limited substrate (Table 1); hence, extents of protein estimated to escape the rumen at $k_{\mathrm{p}}=0.06 / \mathrm{h}$ were correspondingly lower.

Representative plots of $v v s$. [mean S], observed and predicted $\mathrm{S}_{\mathrm{t}} v s . \mathrm{S}_{\mathbf{0}}$, and residual $\mathrm{S}_{\mathrm{t}}$ $v s$. predicted $S_{1}$ are shown for casein, SSBM (10/85) and ESBM (10/85), in Figs. 1, 2 and 3. Plots of $v$ vs. [mean S] from casein (Fig. 1 A) and SSBM (Fig. 2A) displayed typical 

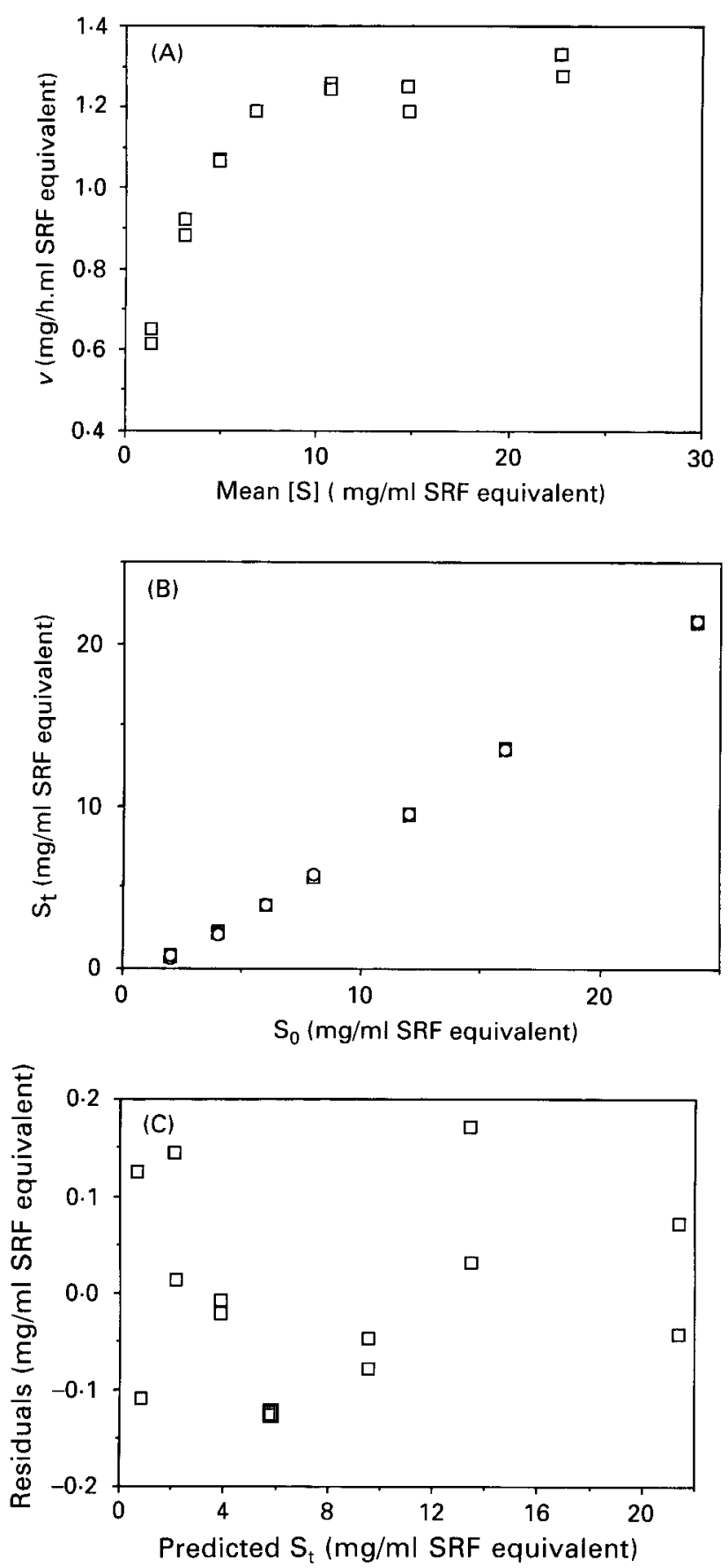

Fig. 1. Expt 1. Representative Michaelis-Menten graphs obtained with casein using data from one of four incubations (7/15/86). (A) Plot of velocity (v) vs. mean substrate concentration (mean [S]); (B) plot of protein remaining undegraded $\left(S_{t}\right)$, observed experimentally $(\square)$ and predicted $(O)$ using the integrated Michaelis-Menten model, $v s$. amounts of protein added $\left(\mathrm{S}_{0}\right)$; (C) plot of residuals (observed $\mathrm{S}_{\mathrm{t}}$ minus predicted $\mathrm{S}_{\mathrm{t}}$ ) $v s$. predicted values for $S_{t}$. For details of procedures, see pp. 28-30. SRF, strained rumen fluid. 

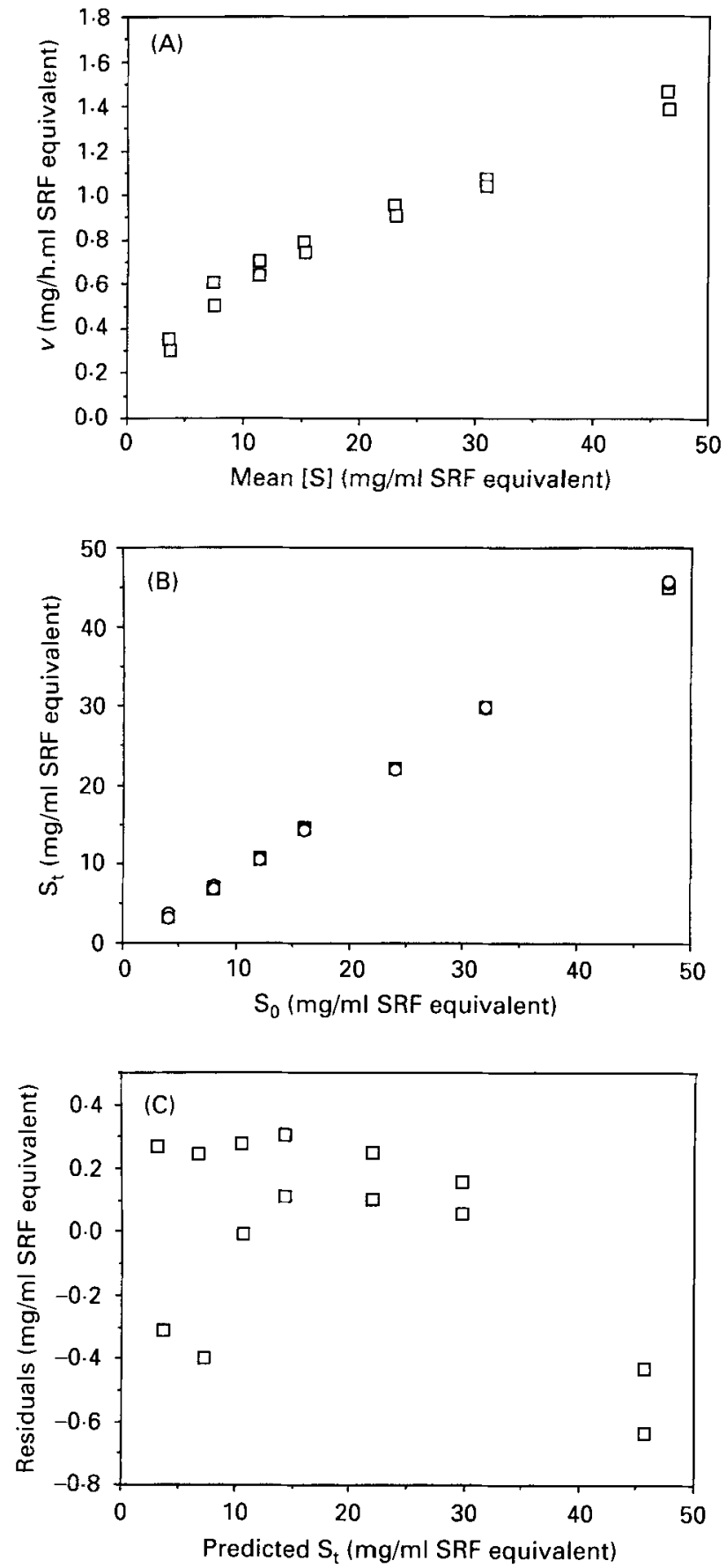

Fig. 2. Expt 1. Representative Michaelis-Menten graphs obtained with solvent-extracted soya-bean meal (SSBM $(10 / 85)$ ) using data from one of four incubations (7/15/86). (A) Plot of velocity (v) vs. mean substrate concentration (mean $[S]$ ); (B) plot of protein remaining undegraded $\left(\mathrm{S}_{\mathrm{t}}\right.$ ), observed experimentally $(\square)$ and predicted $(O)$ using the integrated Michaelis-Menten model, vs. amounts of protein added $\left(\mathrm{S}_{0}\right) ;(\mathrm{C})$ plot of residuals (observed $S_{t}$ minus predicted $S_{t}$ ) vs. predicted values for $S_{t}$. For details of procedures, see pp. $28-30$. 

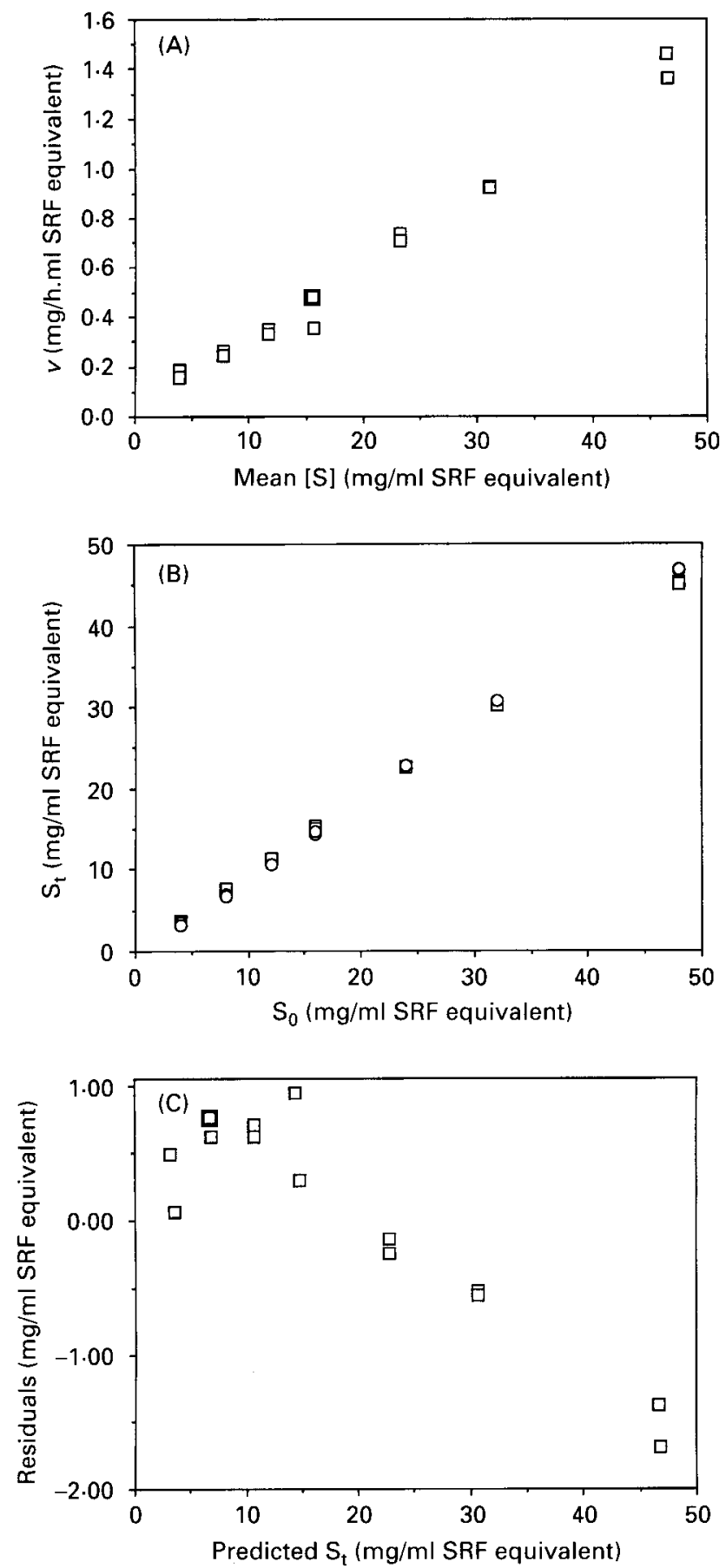

Fig. 3. Expt 1. Representative Michaelis-Menten graphs obtained with expeller-extracted soya-bean meal (ESBM $(10 / 85))$ using data from one of four incubations (7/8/86). (A) Plot of velocity $(v) v s$. mean substrate concentration (mean $[\mathrm{S}])$; (B) plot of protein remaining undegraded $\left(\mathrm{S}_{\mathrm{t}}\right)$, observed experimentally $(\square)$ and predicted $(O)$ using the integrated Michaelis-Menten model, vs. amounts of protein added $\left(\mathrm{S}_{0}\right) ;(C)$ plot of residuals (observed $\mathrm{S}_{\mathrm{t}}$ minus predicted $S_{t}$ ) vs. predicted values for $S_{t}$. For details of procedures see pp. 28-30. 
Table 2. Expt 2. Mean protein degradation rates, $k_{\mathrm{d}}(/ h)$, estimated with the integrated Michaelis-Menten model using data from $1 \mathrm{~h}$ or $2 \mathrm{~h}$ incubations*

(Values are means with their standard errors from four incubations)

\begin{tabular}{|c|c|c|c|}
\hline \multirow[b]{2}{*}{ Protein } & \multicolumn{2}{|c|}{ Incubation period (h) } & \multirow[b]{2}{*}{ Mean } \\
\hline & 1 & 2 & \\
\hline \multicolumn{4}{|l|}{ Casein } \\
\hline Mean & 0.682 & 0.551 & $0.617^{\mathrm{a}}$ \\
\hline $\mathrm{SE}$ & $0 \cdot 102$ & $0 \cdot 062$ & \\
\hline \multicolumn{4}{|l|}{ BSA } \\
\hline Mean & $0.086 \uparrow$ & $0 \cdot 137$ & $0.111^{\mathrm{b}}$ \\
\hline $\mathrm{SE}$ & 0.032 & 0.024 & \\
\hline \multicolumn{4}{|l|}{$\operatorname{SSBM}(1 / 84)$} \\
\hline Mean & $0 \cdot 188$ & $0 \cdot 169$ & $0 \cdot 178^{\mathrm{b}}$ \\
\hline SE & 0.028 & 0.009 & \\
\hline \multicolumn{4}{|l|}{$\operatorname{ESBM}(1 / 84)$} \\
\hline Mean & $0 \cdot 112$ & $0.081+$ & $0.097^{\mathrm{b}}$ \\
\hline $\mathrm{SE}$ & 0.015 & 0.009 & \\
\hline
\end{tabular}

BSA, bovine serum albumin; SSBM, solvent-extracted soya-bean meal; ESBM, expeller-extracted soya-bean meal.

a. b Mean values with unlike superscript letters were significantly different $(P<0 \cdot 05)$.

* For details of procedures, see pp. 28-30.

$\dagger n 3$ due to non-convergence of the integrated Michaelis-Menten model for one of four incubations.

saturation kinetics; good fits to IMM were obtained as judged from observed and predicted (Figs. $1 \mathrm{~B}$ and 2 B), and residual plots (Figs. 1C and 2C). Thus, results with casein and SSBM (10/85) from Expt 1 indicated the IMM was an appropriate model for Michaelis-Menten analysis. However, $v$ vs. [mean S] from ESBM appeared to remain essentially linear (Fig. 3A), and, although observed and predicted plots (Fig. $3 \mathrm{~B}$ ) suggested adequate fit to the IMM, residuals pattern indicated slight under-estimation of $S_{t}$ at low [S] and over-estimation at high [S] (Fig. 3C). Moreover, the non-linear parameter estimation procedure (NLIN) did not converge for two of four ESBM (10/85) incubations and, hence, did not yield useful solutions for $k_{\mathrm{d}}$.

\section{Expt 2}

Four proteins, casein, BSA, SSBM (1/84) and ESBM (1/84) were tested in the Michaelis-Menten system after $1 \mathrm{~h}$ and $2 \mathrm{~h}$ incubations to determine if $2 \mathrm{~h}$ incubations yielded satisfactory IMM estimates of initial rates of degradation. No significant differences were observed among degradation rates, $k_{\mathrm{d}}(P=0.40), V_{\max }(P=0.39)$, and $K_{\mathrm{m}}(P=0 \cdot 22)$ from the four proteins due to time of incubation. Although degradation rates determined for the individual proteins yielded similar overall means at $1 \mathrm{~h}$ and $2 \mathrm{~h}$ (Table 2), greater standard errors indicated rates determined with $1 \mathrm{~h}$ incubations were less stable.

\section{Expt 3}

Estimates of fractional degradation rates made by limited substrate (Broderick, 1987) and IMM methods for twelve different proteins are in Table 3. As observed in Expt 1, the Michaelis-Menten procedure yielded rates for casein which were about twice, and a mean from the four ESBM which was $75 \%$ greater, than those obtained by the limited substrate method. Rates observed for lucerne hay were even more rapid by the Michaelis-Menten methodology. Although SSBM rates also were more rapid, differences between the two approaches were not as great as for the other three protein sources. Degradation rate 


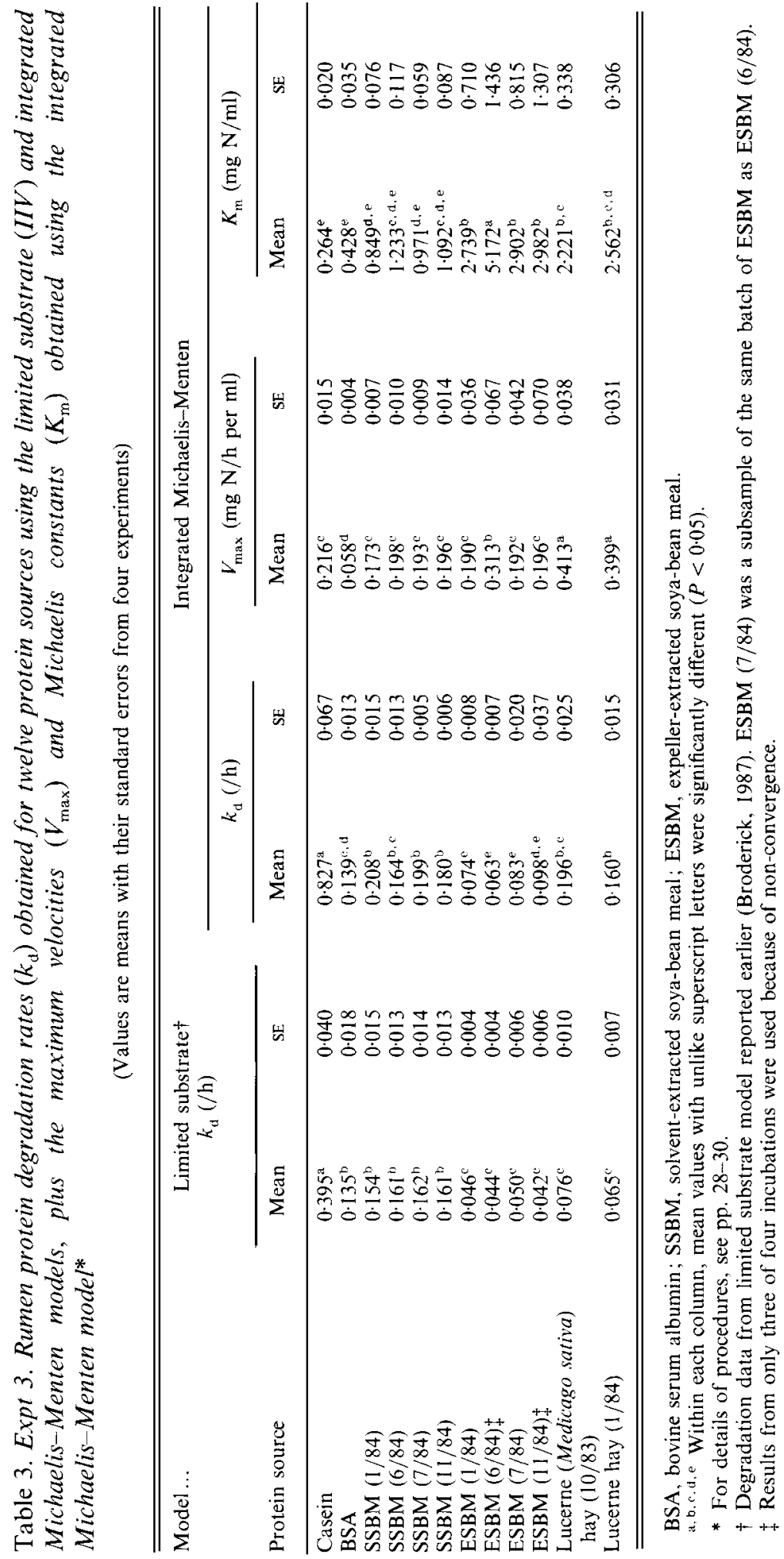


Table 4. Expt 3. Estimated rumen protein escapes (\%) computed for twelve protein sources from degradation rates (Table 3) determined by the limited substrate (IIV) and integrated Michaelis-Menten models*

\begin{tabular}{|c|c|c|c|c|c|}
\hline \multirow{2}{*}{$\begin{array}{l}\text { Model... } \\
\text { Protein source }\end{array}$} & \multirow[b]{2}{*}{$\begin{array}{c}\text { Nitrogen } \\
(\mathrm{g} / \mathrm{kg} \mathrm{DM})\end{array}$} & \multicolumn{2}{|c|}{ Limited substrate $\uparrow$} & \multicolumn{2}{|c|}{$\begin{array}{c}\text { Integrated } \\
\text { Michaelis-Menten }\end{array}$} \\
\hline & & $\begin{array}{l}\text { Intercept } \\
\text { antilog }(B)\end{array}$ & $\begin{array}{l}\text { Estimated } \\
\text { escape }\end{array}$ & $\begin{array}{c}\text { Intercept } \\
\text { antilog }(B) \ddagger\end{array}$ & $\begin{array}{l}\text { Estimated } \\
\text { escape }\end{array}$ \\
\hline Casein & 156 & 101.9 & 13 & 100 & 7 \\
\hline BSA & 159 & 106.9 & 31 & 100 & 30 \\
\hline $\operatorname{SSBM}(1 / 84)$ & 75 & $99 \cdot 6$ & 28 & 100 & 22 \\
\hline SSBM $(6 / 84)$ & 74 & $102 \cdot 0$ & 27 & 100 & 27 \\
\hline SSBM $(7 / 84)$ & 74 & $101 \cdot 4$ & 27 & 100 & 23 \\
\hline SSBM $(11 / 84)$ & 82 & $102 \cdot 9$ & 27 & 100 & 25 \\
\hline $\operatorname{ESBM}(1 / 84)$ & 75 & 97.8 & 55 & 100 & 45 \\
\hline $\operatorname{ESBM}(6 / 84) \S$ & 72 & $97 \cdot 5$ & 56 & 100 & 49 \\
\hline $\operatorname{ESBM}(7 / 84)$ & 72 & $97 \cdot 4$ & 53 & 100 & 42 \\
\hline $\operatorname{ESBM}(11 / 84) \S$ & 72 & $96 \cdot 4$ & 57 & 100 & 38 \\
\hline $\begin{array}{l}\text { Lucerne (Medicago sativa) } \\
\text { hay }(10 / 83)\end{array}$ & 36 & $74 \cdot 3$ & 37 & 91.9 & 22 \\
\hline Lucerne hay $(1 / 84)$ & 31 & $73 \cdot 8$ & 40 & $91 \cdot 0$ & 25 \\
\hline
\end{tabular}

DM, dry matter; BSA, bovine serum albumin; SSBM, solvent-extracted soya-bean meal; ESBM, expellerextracted soya-bean meal.

* For details of procedures, see pp. $28-30$.

$\dagger$ Intercept antilogs $(B)$ and estimated rumen escapes from limited substrate model were reported earlier (Broderick, 1987). ESBM (7/84) was a subsample of the same batch of ESBM as ESBM (6/84).

Intercept antilogs $(B)$ for the integrated Michaelis-Menten model were assumed to be $100 \%$ because $0 \mathrm{~h}$ ammonia plus total amino acids (TAA) accounted for $<1 \%$ of total $\mathrm{N}$ except for lucerne hays. Ammonia plus TAA measured at $0 \mathrm{~h}$ was used to correct $B$-fractions for degraded $\mathrm{N}$ in lucerne hay.

$\S$ Results from only three of four incubations were used because of non-convergence.

obtained by both methods for BSA was nearly identical. Statistical analysis of degradation rates from limited substrate incubations indicated casein was clearly most rapid, with BSA plus SSBM, and ESBM plus lucerne hays forming two other distinct groups. Separation of mean rates from the IMM revealed a different general pattern: after casein, lucerne hays fell into a second group with SSBM having degradation rates in the range $0 \cdot 16-0 \cdot 21 / \mathrm{h}$; BSA was intermediate, and the four ESBM samples formed a group with the slowest rates.

The kinetic constants $V_{\max }$ and $K_{\mathrm{m}}$ for the twelve proteins are also given in Table 3. Except for BSA, which was lower, and the lucerne hays and one ESBM sample, which were higher, $V_{\max }$ values were not significantly different among the other proteins, ranging from 0.17 to $0.22 \mathrm{mg} \mathrm{N} / \mathrm{h}$ per $\mathrm{ml} \mathrm{SRF}$. The Michaelis constant, $K_{\mathrm{m}}$, was approximately inversely related to degradation rate. Since maximum velocity was not significantly different for several proteins with substantially different degradation rates, this reflected differing affinities for rumen microbial degradative enzymes (Segal, 1976) amongst these proteins. However, $K_{\mathrm{m}}$ estimated for BSA was not significantly different from that for casein, despite a sixfold difference in degradation rate.

Extents of rumen escape computed for the twelve proteins are in Table 4 . Of course, the more rapid degradation rates obtained using the IMM approach reduced amounts predicted to escape the rumen, with greater differences from limited substrate results for proteins with slower rates. The most dramatic changes in estimated escape were for casein, lucerne hay, and ESBM, with little or no change for SSBM and BSA. 


\section{Expt 4}

Results from Michaelis-Menten determinations of degradation rates for casein, BSA, SSBM (1/84) and ESBM (1/84), for a mixture of casein and BSA, and for the buffer insoluble protein in SSBM (1/84) and ESBM (1/84), are in Table 5. Degradation rates observed for the four intact proteins were similar to those found previously (Table 3 ), except that the rate for SSBM (1/84) was somewhat higher $(0.28 \mathrm{vs} .0 \cdot 21 / \mathrm{h})$. The rate observed with the equal- $\mathrm{N}$ mixture of casein and BSA was intermediate between those for the two proteins, and, by orthogonal contrast, not significantly different $(P>0 \cdot 10)$ from their average. Degradation rates for the residual proteins prepared from SSBM and ESBM were lower, but not significantly so, compared with their unextracted controls (Table 5). Different effects were observed on $V_{\max }$ and $K_{\mathrm{m}}$. The $V_{\max }$ of the casein-BSA mixture was greater $(P<0.01)$ than the average for the individual proteins. Both $V_{\max }$ and $K_{\mathrm{m}}$ were different $(P<0.05)$ from controls for residual proteins for both SSBM and ESBM (Table $5)$.

\section{DISCUSSION}

\section{$I M M$}

Both the limited substrate procedure and the IMM method can be used to estimate initial, fractional rates of protein degradation by rumen micro-organisms. Estimates of degradation rates are valuable because, provided they truly represent rates occurring in vivo, they may be used with rumen passage rates, $k_{\mathrm{p}}$, to estimate rumen protein escape. Rumen passage rates vary particularly with DM intake (Elimam \& Ørskov, 1984; Shaver et al. 1986). Hence, protein degradation rates could be used in conjunction with $k_{\mathrm{p}}$, varied according to level of DM intake, to develop a dynamic system for predicting protein escape from the rumen. The Agricultural Research Council (1984) has developed such a system based on in situ degradation rates and the rates of rumen passage expected at low, medium and high feed intakes.

Potential advantages of the Michaelis-Menten approach in our IIV system, vs. a limited substrate approach, include: reduced end-product inhibition, improved accuracy due to use of greater quantities of sample and, hence, reduced weighing errors and larger differences between blank and plus-protein vessels in concentrations of the degradative end-products $\mathrm{NH}_{3}$ and TAA. The principal advantage of using direct Michaelis-Menten fit of nontransformed data by NLR is a sounder error structure and reduced likelihood of biased estimates (Cornish-Bowden, 1976; Motulsky \& Ransnas, 1987; Bates \& Watts, 1988). The IMM has the dependent variable $S_{t}$ on both sides of the equation; thus, the SAS-NLR fit to the IMM may be regarded as a first approximation. To address this, we used the minimization routines of the ' $S$ ' statistical analysis language (Becker et al. 1988) to fit a version of the IMM model that incorporated the variability of the dependent variable, $S_{t}$, on both sides of the equation. The resulting estimates of $k_{\mathrm{d}}$ were only slightly different from those obtained by the SAS-NLR 'first approximation'. This is perhaps not too surprising, given the relatively small amounts of residual error observed for the data (cf. Figs. 1, 2 and 3).

\section{Appropriateness of IMM degradation rates}

Rates of degradation $\left(k_{\mathrm{d}}\right)$ obtained using the IMM approach for most proteins were more rapid than those obtained using the limited substrate technique. For example, rates obtained for casein were typically more than twice as fast (Tables 1 and 3). Estimated casein degradation rates of $0.80-0.90 / \mathrm{h}$ may be sounder than the rates of $0.30-0.40 / \mathrm{h}$ obtained by the limited substrate technique, because more rapid rates are more consistent with in vivo rates of digesta passage. Although the $13 \%$ protein escape estimated using the limited substrate rate (Table 4) is similar to reported in vivo escapes of about $10 \%$ (McDonald \& 
Table 5. Expt 4. Comparison of mean protein degradation rates $\left(k_{\mathrm{d}}\right)$, maximum velocities $\left(V_{\max }\right)$ and Michaelis constants $\left(K_{\mathrm{m}}\right)$ obtained for four individual proteins, a mixture of two proteins, and two buffer-extracted protein residues*

(Values are means with their standard errors from four incubations)

\begin{tabular}{|c|c|c|c|}
\hline \multirow[b]{2}{*}{ Protein } & \multicolumn{3}{|c|}{ Michaelis-Menten variable } \\
\hline & $\begin{array}{c}k_{\mathrm{d}} \\
(/ \mathrm{h})\end{array}$ & $\begin{array}{c}V_{\max } \\
(\mathrm{mg} \mathrm{N} / \mathrm{h} \text { per } \\
\mathrm{ml} \mathrm{SRF})\end{array}$ & $\begin{array}{c}K_{\mathrm{m}} \\
(\mathrm{mg} \mathrm{N} / \mathrm{ml} \mathrm{SRF})\end{array}$ \\
\hline \multicolumn{4}{|l|}{ Casein } \\
\hline Mean & $0.783^{a}$ & $0.095^{\mathrm{b}}$ & $0 \cdot 126^{\mathrm{b}}$ \\
\hline SE & $0-102$ & $0 \cdot 008$ & 0.016 \\
\hline \multicolumn{4}{|l|}{ BSA } \\
\hline Mean & $0 \cdot 129^{\mathrm{d}, \mathrm{e}}$ & $0 \cdot 049^{\mathrm{e}}$ & $0.412^{b}$ \\
\hline $\mathrm{SE}$ & $0 \cdot 019$ & $0 \cdot 033$ & 0.079 \\
\hline \multicolumn{4}{|c|}{ Casein + BSA mixture } \\
\hline Mean & $0.557^{\mathrm{b}}$ & $0.092^{\mathrm{b}, \mathrm{c}}$ & $0 \cdot 178^{b}$ \\
\hline SE & $0 \cdot 101$ & $0 \cdot 007$ & $0 \cdot 028$ \\
\hline \multicolumn{4}{|c|}{$\operatorname{SSBM}(1 / 84)$} \\
\hline Mean & $0-28 I^{\circ}$ & $0 \cdot 110^{\mathrm{a}}$ & $0.416^{\mathrm{b}}$ \\
\hline SE & 0.030 & $0-011$ & $0 \cdot 085$ \\
\hline \multicolumn{4}{|c|}{ SSBM (1/84) residue } \\
\hline Mean & $0 \cdot 253^{\mathrm{e}, \mathrm{d}}$ & $0.080^{c}$ & $0 \cdot 356^{\mathrm{b}}$ \\
\hline SE & $0 \cdot 040$ & 0.010 & 0.090 \\
\hline \multicolumn{4}{|c|}{$\operatorname{ESBM}(1 / 84)$} \\
\hline Mean & $0.073^{e}$ & $0 \cdot 103^{a, b}$ & $1.435^{\mathrm{a}}$ \\
\hline SE & 0.006 & $0 \cdot 007$ & $0 \cdot 151$ \\
\hline \multicolumn{4}{|c|}{ ESBM $(1 / 84)$ residue } \\
\hline Mean & $0.047^{\circ}$ & $0.067^{\mathrm{a}}$ & $1.597^{\mathrm{a}}$ \\
\hline SE & 0.011 & $0 \cdot 003$ & $0 \cdot 254$ \\
\hline
\end{tabular}

SRF, strained rumen fluid; BSA, bovine serum albumin; SSBM, solvent-extracted soya-bean meal; ESBM, expeller-extracted soya-bean meal.

$a, b, c, d,:$ Within each column, mean values with unlike superscript letters were significantly different $(P<0.05)$.

* For details of procedures, see pp. $28-30$.

Hall, 1954; Broderick, 1978), the passage rate of $0.06 / \mathrm{h}$ used in its computation is typical for rumen DM in dairy cows consuming feed DM equivalent to 0.03-0.04 of body-weight (Shaver et al. 1986). However, casein probably flows largely with the liquid phase. Liquids pass out of the rumen at rates about twice that of DM (Broderick et al. 1991). A rumen passage rate $\left(k_{\mathrm{p}}\right)$ of $0.12 / \mathrm{h}$ would yield estimated escapes of 13 and $23 \%$ at the degradation rates of 0.80 and $0.40 /$ h obtained by IMM and limited substrate methodology respectively. The IMM rates for lucerne hay of $0 \cdot 16-0.20 \mathrm{~h}$ (Table 3) yielded estimates of rumen protein escape of $22-25 \%$ (Table 4 ) which are more consistent with the value of $28 \%$ rumen escape assigned to lucerne hay by the (US) National Research Council (1988).

Degradation rates obtained for samples of SSBM and ESBM also were more rapid by the IMM procedure (means of 0.16 vs. 0.19 for SSBM and 0.046 vs. $0.080 \mathrm{~h}$ for ESBM; Table 3), although these differences were not of the same magnitude as for casein and lucerne hay. The mean rumen escapes of 27 and $24 \%$ (Table 4), predicted for SSBM protein from limited substrate and IMM data, are lower than the mean $35 \%$ escape reported by the (US) National Research Council (1988). The (US) National Research Council (1988) has not reported rumen protein escapes for ESBM. Computation of relative rumen escape assuming $k_{\mathrm{p}}, 0.06 / \mathrm{h}$ indicated that ESBM protein had 103 and $79 \%$ greater escape than SSBM protein, based on degradation rates from limited substrate and IMM 
methods respectively (Table 4). One in vivo determination of relative rumen escape (Broderick, 1986) and three lactation studies (Broderick et al. 1990) indicated that the mean in vivo effectiveness of ESBM protein was $70 \%$ greater than SSBM protein.

The degradation rate observed for BSA was essentially equal by limited substrate and IMM methodology (Table 3); BSA rates were similar across all three studies in which they were determined (Tables 2, 3 and 5).

Occasionally, very rapid degradation rates were observed by the IMM procedure for casein, contributing to rather larger standard errors than for other proteins (cf. Tables 1 , 2, 3 and 5). It seems possible that this increased variability may be related to greater fluctuation of protein degradative activity in the rumen which is directed toward soluble, more degradable proteins. Although proteolytic activity in the cell-free supernatant fraction from rumen fluid is usually low (Brock et al. 1982), Blackburn (1968) reported that Bacteroides amylophilus released as much as $20 \%$ of total protease into the medium during later phases of growth. Cotta \& Hespell (1986) observed that several strains of Butyrivibrio fibrisolvens, an important proteolytic organism in the rumen, produced extensive amounts of extracellular protease under some culture conditions.

\section{Kinetic considerations}

The lack of significant difference between rates determined in $1 \mathrm{~h} v s .2 \mathrm{~h}$ incubations suggested that end-product inhibition was not significant by $2 \mathrm{~h}$. We believe the system is more stable, as indicated by lower standard errors for rates obtained with the $2 \mathrm{~h}$ incubations, than when incubations are run for only $1 \mathrm{~h}$ (Table 2).

Protein in most ruminant diets probably consists of mixtures of rapidly and slowly degraded fractions. We were concerned that 'IMM' incubations, which employ increasingly large amounts of protein, might yield overall degradation rates for feed proteins which are influenced too greatly by rapidly degraded fractions which might represent, in some cases, minor proportions of the total. The degradation rate observed for a mixture of equal parts of $\mathrm{N}$ from casein and BSA was intermediate between the rates for the individual proteins (Table 5), and was not different from the average of the two. It can be shown mathematically that, assuming competition among the substrates for the same degradative enzymes (Segal, 1976), $k_{\mathrm{d}}$, the $V_{\max }: K_{m}$ ratio, for a mixture of two compounds is equal to the weighted mean of the $k_{\mathrm{d}}$ for the individual compounds, the weights being proportional to the concentrations of the compounds. Degradation rates for SSBM and ESBM were not significantly different from those for their residual, buffer insoluble proteins (Table 5). This is particularly remarkable for SSBM because the McDougall's buffer extraction removes about $270 \mathrm{~g} \mathrm{~N} / \mathrm{kg}$ total $\mathrm{N}$ (Broderick, 1986). Thus, it appears that degradation rates estimated using the IMM approach will not be skewed by rapidly degraded fractions, and rates obtained for feed proteins are probably representative of degradation of the feedstuff as a whole.

The actual incubation studies described here were conducted over a period of 4.5 years (July 1985-February 1990). Fractional degradation rates observed for the proteins tested over this period were very stable. However, $V_{\max }$ and $K_{\mathrm{m}}$ varied more, and tended to be lower in Expt 4 (conducted February 1990). Some of the variability between incubations was found earlier to be due to differences in inoculum DM concentration (Furchtenicht \& Broderick, 1987). Over the course of these studies, inoculum DM ranged from 20.7 to $42.1 \mathrm{mg} / \mathrm{ml}$; presumably microbial biomass also varied to a similar degree. Expressing $V_{\max }$ and $K_{\mathrm{m}}$ on the basis of inoculum DM rather than SRF did not, however, remove all variation across these studies: values of $V_{\max }(\mathrm{mg} \mathrm{N} / \mathrm{h}$ per $\mathrm{g}$ inoculum $\mathrm{DM})$ ranged from $4 \cdot 1$ to $7 \cdot 8,4 \cdot 2$ to $7 \cdot 4$, and $2 \cdot 3$ to $7 \cdot 6$, and values for $K_{\mathrm{m}}$ (mg N/g inoculum DM) ranged from $5 \cdot 5$ to $15 \cdot 1,20 \cdot 1$ to $44 \cdot 8$, and $49 \cdot 9$ to $98 \cdot 4$, for casein, SSBM, and ESBM respectively. 
As with the limited substrate assay described earlier for use with the IIV system (Broderick, 1987), the IMM method was used to estimate the initial rates of protein degradation in the rumen. In application of the rate concept, it was assumed that the initial rate, measured during $2 \mathrm{~h}$ 'IMM' incubations, or $4 \mathrm{~h}$ 'limited substrate' incubations, described degradation over the entire mean retention time for that protein in the rumen. We have for most of the present discussion assumed a mean retention time of $1 / 0.06=16.7 \mathrm{~h}$. Little deviation from initial rates was observed for most proteins over the course of $4 \mathrm{~h}$ 'limited substrate' incubations. The only exception was BSA, which accelerated with time (Broderick \& Craig, 1989).

Behaviour of the IMM was generally excellent when applied to $2 \mathrm{~h}$ data for most proteins. However, for samples of ESBM, the NLR procedure failed to converge in five out of twenty-eight cases in Expts 1-3. Inspection of plots of velocity vs. [mean S] (e.g. Fig. 3A) suggested that, for this slowly degraded protein, there was little of the curvilinearity indicative of saturation kinetics over the range of substrate concentrations used in these experiments. Therefore, in Expt 4, an additional, higher protein concentration was included for both SSBM and ESBM at $36 \mathrm{mg} \mathrm{N} /$ tube $(8 \mathrm{mg} \mathrm{N} / \mathrm{ml} \mathrm{SRF}$ equivalent). On inclusion of the higher protein concentration, all four ' $\mathrm{IMM}$ ' runs converged and yielded a mean degradation rate for ESBM $(1 / 84)$ of $0.073 / \mathrm{h}$ (Table 5) which was similar to the mean for $\operatorname{ESBM}(1 / 84)$ of $0.078 / \mathrm{h}$ from Expts 2 and 3 (Tables 2 and 3). Rates estimated for SSBM $(1 / 84), 0 \cdot 281$ and $0.306 / \mathrm{h}$, with and without the data at $36 \mathrm{mg} \mathrm{N} /$ tube were not significantly different $(P>0 \cdot 3)$. We suggest that a working protocol for determining degradation rates for unknown proteins could be inclusion of eight protein levels : $2 \cdot 5,5 \cdot 0,10,15,20,30,40$ and $50 \mathrm{mg} \mathrm{N} /$ tube. If initial results indicate very rapid degradation rates (e.g. $>0.40 / \mathrm{h}$ ), then a check of residual plots from the fitted model would help identify whether endproduct inhibition or other deviations had occurred, and velocities obtained at higher protein levels could be deleted from the final IMM rate determinations. The protocol for quantifying degradation rates also must include $0 \mathrm{~h}$ incubations, where microbial activity has been stopped before incubation by adding TCA to tubes before inoculum, to allow correction for degraded $\mathrm{N}$ present as $\mathrm{NH}_{3}$ and free-TAA. This correction was used for lucerne hays which contained $80-90 \mathrm{~g} \mathrm{~N} / \mathrm{kg}$ total $\mathrm{N}$ as $\mathrm{NH}_{3}$ and free-TAA (Expt 3; Tables 3 and 4). Background correction will be even more important when the IMM method is applied to feedstuffs, such as lucerne silages (Muck, 1987) or grass silages (McDonald, 1981), which contain large proportions of degraded $\mathrm{N}$.

\section{Conclusions}

The IMM approach, where fractional rates of protein degradation are estimated using NLR methods from: $k_{\mathrm{d}}=V_{\max }: K_{\mathrm{m}}$, offers a reliable alternative for determining rumen degradability of feed proteins. This approach yielded statistically sound and reproducible estimates of degradation rate, and biologically meaningful estimates of rumen protein escape, for casein, lucerne hay, SSBM and ESBM.

The authors wish to thank Dr M. J. Jackson and Mr D. B. Ricker for assistance in conducting in vitro incubations, Miss H.C. Mier for sample analysis, and Dr M.J. Lindstrom for assistance in applying the ' $S$ ' minimization routines.

\section{REFERENCES}

Agricultural Research Council (1984). The Nutrient Requirements of Ruminant Livestock, Suppl. no. 1. Slough: Commonwealth Agricultural Bureaux.

Association of Official Analytical Chemists (1980). Official Methods of Analysis, 13th ed. Washington, DC: Association of Official Analytical Chemists. 
Bates, D. M. \& Watts, D. G. (1988). Nonlinear Regression Analysis and Its Applications. New York: John Wiley $\&$ Sons.

Becker, R. A., Chambers, J. M. \& Wilks, A. R. (1988). The New S Language: A Programming Environment for Data Analysis and Graphics. Pacific Grove, CA: Wadsworth \& Brooks/Cole.

Blackburn, T. H. (1968). Protease production by Bacteroides amylophilus strain H18. Journal of General Microbiology 53, 27-36.

Brock, F. M., Forsberg, C. W. \& Buchanan-Smith, J. G. (1982). Proteolytic activity of rumen microorganisms and effects of proteinase inhibitors. Applied and Environmental Microbiology 44, 561-569.

Broderick, G. A. (1978). In vitro procedures for estimating rates of ruminal protein degradation and proportions of protein escaping the rumen undegraded. Journal of Nutrition 108, 181-190.

Broderick, G. A. (1986). Relative value of solvent and expeller soybean meal for lactating dairy cows. Journal of Dairy Science 69, 2948-2958.

Broderick, G. A. (1987). Determination of protein degradation rates using a rumen in vitro system containing inhibitors of microbial nitrogen metabolism. British Journal of Nutrition 58, 463-475.

Broderick, G. A. \& Craig, W. M. (1989). Metabolism of peptides and amino acids during in vitro protein degradation by mixed rumen organisms. Journal of Dairy Science 72, 2540-2548.

Broderick, G. A., Ricker, D. B. \& Driver, L. S. (1990). Expeller soybean meal and corn by-products versus solvent soybean meal for lactating dairy cows. Journal of Dairy Science 73, 453-462.

Broderick, G. A., Wallace, R. J. \& Ørskov, E. R. (1991). Control of rate and extent of protein degradation. In Physiological Aspect of Digestion and Metabolism in Ruminants, pp. 541-592 [T. Tsuda, Y. Sasaki and R. Kawashima, editors]. Orlando, FL: Academic Press.

Broderick, G. A., Wallace, R. J., Ørskov, E. R. \& Hansen, L. (1988). Comparison of estimates of ruminal protein degradation by in vitro and in situ methods. Journal of Animal Science 66, 1739-1745.

Cornish-Bowden, A. (1976). Principles of Enzyme Kinetics. Boston: Butterworths.

Cotta, M. A. \& Hespell, R. B, (1986). Proteolytic activity of the ruminal bacterium Butyrivibrio fibrisolvens. Applied and Environmental Microbiology 52, 51-58.

Craig, W. M. \& Broderick, G. A. (1981). Comparison of nitrogen solubility in three solvents to in vitro protein degradation of heat-treated cottonseed meal. Journal of Dairy Science 64, 769-774.

Craig, W. M., Hong, B. J., Broderick, G. A. \& Bula, R. J. (1984). In vitro inoculum enriched with particleassociated microorganisms for determining rates of fibre digestion and protein degradation. Journal of Dairy Science 67, 2902-2909.

Elimam, M. E. \& Ørskov, E. R. (1984). Factors affecting the outflow of protein supplements from the rumen. 1. Feeding level. Animal Production 38, 45-51.

Faldet, M. A., Broderick, G. A., Satter, L. D. \& Ricker, D. B. (1988). Optimizing heat-treatment of full fat soybeans to maximize protein availability. Journal of Dairy Science 71, Suppl. 1, 158.

Faldet, M. A. \& Satter, L. D. (1991). Feeding heat-treated full fat soybeans to cows in early lactation. Journal of Dairy Science 74, 3047-3054.

Furchtenicht, J. E. \& Broderick, G. A. (1987). Effect of inoculum preparation and dietary energy on microbial numbers and rumen protein degradation activity. Journal of Dairy Science 70, 1404-1410.

Lee, H.-J. \& Wilson, I. B. (1971). Enzymic parameters: measurement of $V$ and $K_{m}$. Biochimica et Biophysica Acta 242, 519-522.

McDonald, I. W. \& Hall, R. J. (1954). The conversion of casein into microbial proteins in the rumen. Biochemical Journal 67, 400405.

McDonald, P. (1981). The Biochemistry of Silage. New York: John Wiley \& Sons.

Mahler, H. R. \& Cordes, E. H. (1966). Biological Chemistry. New York: Harper and Row.

Muck, R. E. (1987). Dry matter level effects on alfalfa silage quality. I. Nitrogen transformations. Transactions of the American Society of Agricultural Engineers 30, 7-14.

Motulsky, H. J. \& Ransnas, L. A. (1987). Fitting curves to data using nonlinear regression: a practical and nonmathematical review. FASEB Journal 1, 365-374.

National Research Council (1988). Nutrient Requirements of Dairy Cattle, 6th revised edn (update, 1989). Washington, DC: National Academy Press.

Nocek, J. E. (1988). In situ and other methods to estimate ruminal protein and energy digestibility: a review. Journal of Dairy Science 71, 2051-2069.

Oldham, J. D., Napper, D. J., Smith, T. \& Fulford, R. J. (1985). Performance of dairy cows offered isonitrogenous diets containing urea or fishmeal in early and mid-lactation. British Journal of Nutrition 53, 337-346.

Ørskov, E. R., Reid, G. W. \& Tait, C. A. G. (1987). Effect of fish meal on the mobilization of body energy in dairy cows. Animal Production 45, 345-348.

Segal, I. (1976). Biochemical Calculations, 2nd edn. New York: John Wiley \& Sons.

Shaver, R. D., Nytes, A. J., Satter, L. D. \& Jorgenson, N. A. (1986). Influence of amount of feed intake and forage physical form on digestion and passage of prebloom alfalfa hay in dairy cows. Journal of Dairy Science 69, 1545-1559.

Statistical Analysis System (1985). SAS User's Guide: Statistics, 5th edn. Cary, NC: SAS Institute. 